\title{
Raised Hs-Crp Levels, Low Vitamin D Levels and High Diastolic Blood Pressure-Emerging as Strong Predictors of Type 2 Diabetes MellitusPopulation
}

\author{
Mini Sheth* \\ Department of Foods and Nutrition, The Maharaja Sayajirao University of Baroda, India
}

*Corresponding author: Mini Sheth, Department of Foods and Nutrition, Faculty of Family and Community Sciences, The Maharaja Sayajirao University of Baroda, Gujarat, India

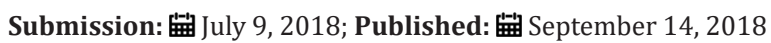

Keywords: Type 2 diabetes mellitus; High h-CRP; Low vitamin D; High diastolic pressure

\section{Introduction}

Diabetes is a complex and chronic illness requiring persistent medical care. The prevalence of diabetes is increasing all over the world at an alarming rate [1] and is a growing public health problem in both developed and developing countries. It can be controlled but not cured. Insufficient insulin, insulin resistance or insulin insensitivity leads to type 2 diabetes mellitus. Due to this, body cells are not able to utilize the glucose and ultimately lead to hyperglycaemia. Long term uncontrolled diabetes mellitus affect the metabolism of the body. Uncontrolled diabetes mellitus leads to raised serum triglycerides, very low density lipoproteins (VLDL) and cholesterol [2]. On the other hand, low HDL was seen to be associated with Diabetes [3].

Apart from this, free radical is formed in diabetes by nonenzymatic glycation of proteins, glucose oxidation and increased lipid peroxidation that leads to damage of various liver enzymes [4]. Another most vital organ affected in diabetes is kidneys. It contributes greatly to the significant proportion of the burden of renal damage and dysfunction [5]. Adler et al. [6] studied the progression from microalbuminuria to macroalbuminuria that lead to elevated serum creatinine. In a retrospective study of diabetic subjects, the authors found that hs-CRP levels are correlated with HbA1c levels. Mean HbA1c levels were significantly higher in patients who had hs-CRP levels of $1 \mathrm{mg} / \mathrm{L}$ or more. Rodríguez M et al. [7] showed that 93\% diabetic subjects had elevated serum Creactive protein levels. Thus, shows that hyper glycemia is related factor to elevated serum hsCRP levels in non-controlled type II diabetic subjects [7].

Homocysteine is another inflammatory marker, which when gets elevated causes adverse effect through mechanism involving oxidative damage. Hyper homo cysteinemia has emerged as a risk factor for cardiovascular diseases. There has been shown some relationship between elevated homocysteine levels and diabetes mellitus. However, its role in the onset of diabetes is unclear [8].

Many studies have shown that pathogenic bacteria count is significantly high and beneficial bacteria count is low in diabetic subjects. A cross sectional study by Mahendra A et al. [9] conducted in Vadodara, revealed that LAB (Lactic Acid Bacteria) and Bifido bacteria were significantly negatively associated with FBS, PP2BSs and HbA1C. Other researchers, Wu X et al. [10] showed that there is lower establishment of colonies of bifidobacteria in diabetic subjects resulting in reduced intestinal permeability and increased endo toxaemia [10]. Thus, diabetes mellitus is a group of metabolic disorder. Long term elevation of glucose in the blood alters the metabolism of body gradually that leads to other health complications.

\section{Materials and Method}

A cross-sectional study was undertaken wherein two private clinics of Vadodara were conveniently selected based on the permission obtained from the doctor to enrol diabetic subjects. A total of 47 subjects were screened and enrolled as per the inclusion and exclusion criteria. Subjects were briefed on the objectives and benefits of the study and written and verbal information were provided. The subjects who willingly signed the written informed consent form were enrolled for the study (Figure 1).

\section{Inclusion criteria for selection of patients}
A. Adult stable type 2 diabetic subjects
B. Willingness to participate in the study
C. Physician's consent. 


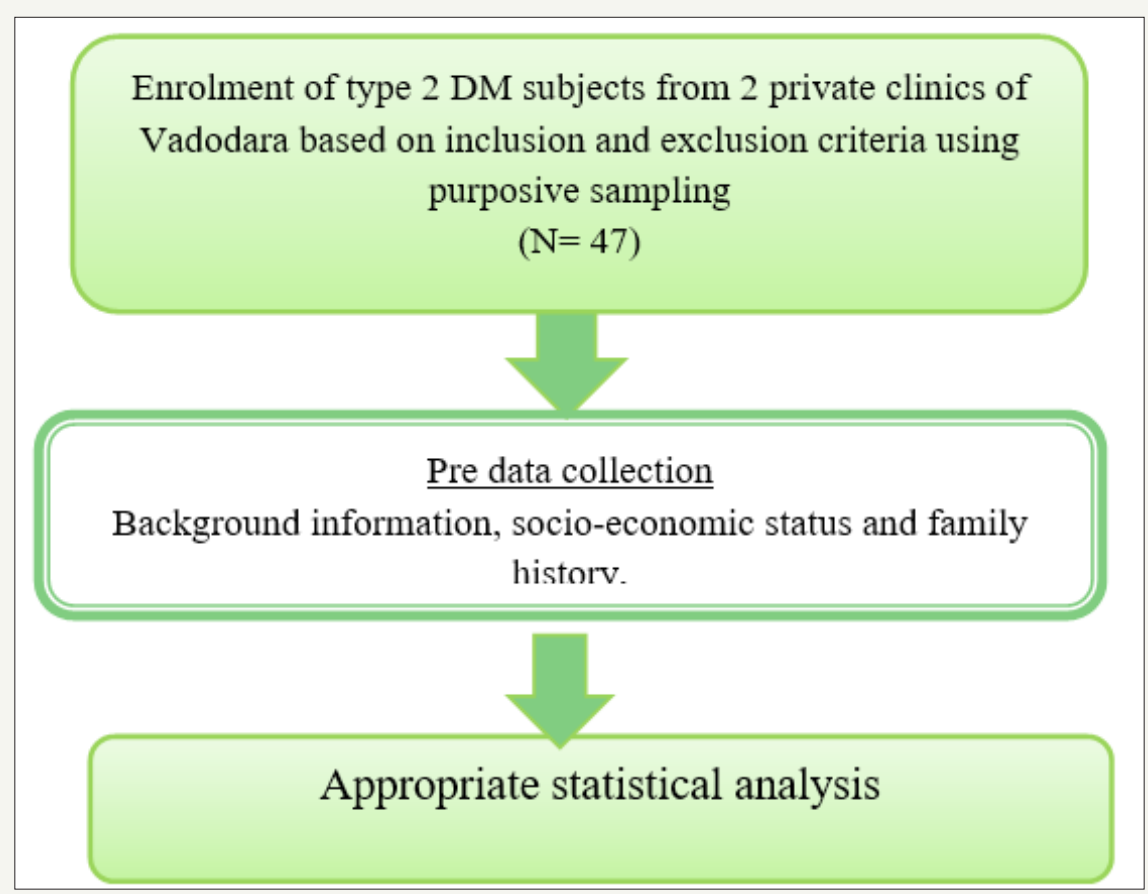

Figure 1: Experimental design of the study.

\section{Exclusion criteria for selection of patients}
A. History of chronic illness
B. Smokers or tobacco chewers
C. $\operatorname{HbA} 1 \mathrm{c} \geq 10$

\section{Collection of general information, anthropometry, biophysical and biochemical parameters}

Baseline information regarding age, gender of subjects was obtained using a pretested semi-structured questionnaire and the socio economic status was collected from the subjects using the Kuppuswamy's Socioeconomic Status Scale 2012 [11]. Anthropometric measurement, weight was measured using bathroom weighing scale. Height was measured using height meter. Then the patient's body mass index (BMI) was calculated using standard formula based on Asia Pacific classifications. The waist circumference of the subject was taken using WHO STEPS protocol for measuring waist circumference through measuring tape. Hip circumference was measured using measuring tape by placing around the widest portion of the buttocks. Waist Hip Ratio was calculated using Waist Circumference and Hip Circumference and Waist Stature Ratio was calculated using Waist Circumference and Height. Sitting blood pressure of subjects was measured using the standard sphygmomanometer on the right arm. All anthropometric measurements were assessed using the guidelines adopted at the NIH sponsored Arlie Conference [12].

The blood and fecal sample were collected before and at the end of the intervention trial and were collected in the fasting state. Trained Laboratory technician from Thyro care pathology lab helped to draw the blood ( $5 \mathrm{ml}$ ). Fasting blood sugar level, glycated haemoglobin, Fructos amine, urinary glucose, hs-CRP and urinary microalbumin were analysed using GOD/POD Enzymatic
Method, Fully automated H.P.L.C, Nitroblue tetrazolium assay, Dipstick method of urinalysis, Nephelometry and Fully automated immuno turbidometry respectively. Vitamin D and homocysteine were analysed using Chemi luminescent immunoassay. Average blood sugar was derived from glycated haemoglobin. The gut microbial analysis was determined in terms of Bifidobacterium and Lactobacilli and E.coli [13].

\section{Ethical clearance}

The study was approved by The Institutional Ethics Committee for Human Research (IECHR) of the Foods and Nutrition Department, The M.S. University of Baroda and the ethical number allotted for the study was IECHR/2017/6.

\section{Statistical analysis}

The data was entered in an excel spreadsheet. The data was cleaned and verified and subjected to appropriate statistical analysis. Statistical analysis was performed using Microsoft Excel 2013. Results were expressed as mean values \pm standard deviations. Correlation coefficient was computed amongst the parameters of interest.

\section{Results}

Out of forty seven subjects screened, $38.3 \%$ were males and $61.7 \%$ were females. About $14.8 \%$ and $72.5 \%$ subjects were overweight and obese respectively and $70 \%$ of the subjects had abdominal obesity indicating high risk for development of NCDs (Table 1). It was observed that $40.5 \%$ of the subjects had hypertension. Males were more hypertensive than females (Table 2). $50 \%$ of the obese DM subjects suffered from hypertension and almost $85 \%$ of the non-obese DM subjects was in pre-hypertension stage (Table 3). 
Table 1: Classification of subjects according to BMI.

\begin{tabular}{|c|c|c|c|}
\hline $\begin{array}{c}\text { Classification of BMI } \\
\left(\mathbf{K g} / \mathbf{m}^{2}\right)\end{array}$ & $\begin{array}{c}\text { Male } \\
\mathbf{( N = 1 8 )}\end{array}$ & $\begin{array}{c}\text { Female } \\
\mathbf{N}=\mathbf{2 9}\end{array}$ \\
\hline Underweight $(<18.5)$ & $0(0)$ & $0(0)$ & $\begin{array}{c}\text { Total } \\
\mathbf{N}=\mathbf{4 7}\end{array}$ \\
\hline Normal $(18.5-22.9)$ & $3(16.6)$ & $3(10.3)$ & $6(12.7)$ \\
\hline Overweight $(23-24.9)$ & $2(11.1)$ & $5(17.2)$ & $7(14.8)$ \\
\hline Obese $(\geq 25)$ & $13(72.3)$ & $21(72.5)$ & $34(72.5)$ \\
\hline
\end{tabular}

Note: Figure in parenthesis represent percent of subjects

Source: Asia pacific classification, 2004

Table 2: Number of type 2 DM subjects with Hypertension.

\begin{tabular}{|c|c|c|c|}
\hline $\begin{array}{l}\text { Hypertension Classification } \\
\text { (mmHg) }\end{array}$ & $\begin{array}{l}\text { Male } \\
\mathrm{N}=18\end{array}$ & $\begin{array}{c}\text { Female } \\
\mathrm{N}=29\end{array}$ & $\begin{array}{l}\text { Total } \\
\mathrm{N}=47\end{array}$ \\
\hline $\begin{array}{c}\text { Normal } \\
(\mathrm{SBP}<120 \text { and } \mathrm{DBP}<80\end{array}$ & $3(16.6)$ & $4(13.8)$ & $7(14.8)$ \\
\hline $\begin{array}{c}\text { Prehypertension } \\
\text { (SBP 120-139 or DBP 80-89) }\end{array}$ & $5(27.8)$ & $16(55.2)$ & $21(44.7)$ \\
\hline $\begin{array}{c}\text { Moderate Hypertension } \\
\text { (SBP } 140-160 \text { or DBP } 90-110 \text { ) }\end{array}$ & $8(44.4)$ & $5(17.2)$ & $13(27.7)$ \\
\hline $\begin{array}{c}\text { Severe Hypertension } \\
(\mathrm{SBP}>160 \text { or } \mathrm{DBP}>110)\end{array}$ & $2(11.1)$ & $4(13.8)$ & $6(12.8)$ \\
\hline
\end{tabular}

Note: Figure in parenthesis represent percent of subjects.

SBP: Systolic Blood Pressure; DBP: Diastolic Blood Pressure

Source: American Heart Association, 2011

Table 3: Prevalence of hypertension in obese and non-obese DM subjects

\begin{tabular}{|c|c|c|c|c|}
\hline $\begin{array}{l}\text { Hypertension Classification } \\
\text { (mmHg) }\end{array}$ & $\begin{array}{c}\text { Nonobese } \\
\text { DM } \\
\mathrm{N}=13\end{array}$ & $\begin{array}{c}\text { Obese } \\
\text { DM } \\
\mathrm{N}=34\end{array}$ & Chi-Square & p-Value \\
\hline $\begin{array}{c}\text { Normal } \\
(\mathrm{SBP}<120 \text { and } \mathrm{DBP}<80\end{array}$ & $1(7.6)$ & $5(14.7)$ & \multirow{2}{*}{$9.43^{* *}$} & \multirow{2}{*}{0.008} \\
\hline $\begin{array}{c}\text { Prehypertension } \\
\text { (SBP }<139 \text { or DBP < } 89 \text { ) }\end{array}$ & $11(84.6)$ & $12(35.2)$ & & \\
\hline $\begin{array}{c}\text { Hypertension } \\
(\mathrm{SBP} \geq 140 \text { or } \mathrm{DBP} \geq 90)\end{array}$ & $1(7.6)$ & $17(50.1)$ & & \\
\hline
\end{tabular}

Note: Figure in parenthesis represent percent of subjects.

**P value<0.01, SBP: Systolic Blood Pressure; DBP: Diastolic Blood Pressure 
The mean FBS, average blood sugar level, HbA1c, fructosamine and urinary glucose were $158.5 \pm 40.6,190.8 \pm 49.3,8.25 \pm 1.72$, $279.7 \pm 54.8$ and $42.5 \pm 49.2$. The mean hs-CRP and homocysteine of the subjects were $3.17 \mathrm{mg} / \mathrm{L}$ and $22.6 \mu \mathrm{mol} / \mathrm{L}$ respectively. The mean counts of stool samples for Lactobacillus, Bifidobacterium and E. coli were 5.6, 5.5 and 4.5 respectively. There was no significant difference between the mean log counts of the gut microflora in males and females (Table 4).

Table 4: Mean values for glycemic status, inflammatory status and gut microflora of type 2 DM subjects.

\begin{tabular}{|c|c|c|c|c|c|}
\hline Parameters & $\begin{array}{l}\text { Male } \\
\mathrm{N}=18\end{array}$ & $\begin{array}{c}\text { Female } \\
\mathrm{N}=29\end{array}$ & 't' Value & $\begin{array}{l}\text { Total } \\
\mathrm{N}=47\end{array}$ & Normal Values \\
\hline $\begin{array}{l}\text { Fasting Blood sugar } \\
(\mathrm{mg} / \mathrm{dL})\end{array}$ & $144.95 \pm 33.3$ & $166.9 \pm 51.9$ & $1.75^{\mathrm{NS}}$ & $158.5 \pm 40.6$ & $<110 \mathrm{mg} / \mathrm{dL}$ \\
\hline $\begin{array}{l}\text { Average Blood glucose } \\
\qquad(\mathrm{mg} / \mathrm{dL})\end{array}$ & $179.61 \pm 43.5$ & $196.5 \pm 52.5$ & $1.2^{\mathrm{NS}}$ & $190.8 \pm 49.3$ & $<120 \mathrm{mg} / \mathrm{dL}$ \\
\hline $\begin{array}{l}\mathrm{HbA1c} \\
(\%)\end{array}$ & $7.8 \pm 1.51$ & $8.47 \pm 1.82$ & $1.19^{\mathrm{NS}}$ & $8.25 \pm 1.72$ & $<6.5 \%$ \\
\hline $\begin{array}{l}\text { Fructosamine } \\
\qquad(\mu \mathrm{mol} / \mathrm{L})\end{array}$ & $288 \pm 40.7$ & $274.6 \pm 62.5$ & $0.89^{\mathrm{NS}}$ & $279.7 \pm 54.8$ & $<286 \mu \mathrm{mol} / \mathrm{L}^{\#}$ \\
\hline $\begin{array}{l}\text { Urinary Glucose } \\
\text { (mg/dL) }\end{array}$ & $55.5 \pm 50.2$ & $34.4 \pm 39.9$ & $0.90^{\mathrm{NS}}$ & $42.5 \pm 49.2$ & negative \\
\hline $\begin{array}{l}\text { hs-CRP } \\
(\mathrm{mg} / \mathrm{L})\end{array}$ & $2.32 \pm 1.80$ & $3.69 \pm 3.7$ & $1.63^{\mathrm{NS}}$ & $3.17 \pm 3.29$ & $<3 \mathrm{mg} / \mathrm{L}^{\# \#}$ \\
\hline $\begin{array}{l}\text { Homocysteine } \\
(\mu \mathrm{mol} / \mathrm{L})\end{array}$ & $28.16 \pm 14.3$ & $19.12 \pm 10.2$ & $2.04^{*}$ & $22.6 \pm 13.52$ & $<30 \mu \mathrm{mol} / \mathrm{L}^{* *}$ \\
\hline $\begin{array}{c}\text { E.coli } \\
\text { Log10 } \\
\text { (CFU/g) }\end{array}$ & $4.50 \pm 1.43$ & $4.85 \pm 1.54$ & $1.28^{\mathrm{NS}}$ & $4.68 \pm 1.55$ & - \\
\hline $\begin{array}{c}\text { Bifidobacterium } \\
\log _{10} \\
(\mathrm{CFU} / \mathrm{g})\end{array}$ & $5.58 \pm 1.54$ & $5.96 \pm 1.63$ & $0.89^{\mathrm{NS}}$ & $5.36 \pm 1.80$ & - \\
\hline $\begin{array}{l}\text { Lactobacillus } \\
\log _{10} \\
(\mathrm{CFU} / \mathrm{g})\end{array}$ & $5.69 \pm 1.59$ & $5.07 \pm 1.87$ & $1.12^{\mathrm{NS}}$ & $5.78 \pm 1.58$ & - \\
\hline $\begin{array}{l}\text { Vitamin D } \\
\text { (ng/mL) }\end{array}$ & $17.01 \pm 8.94$ & $15.69 \pm 7.3$ & $1.1^{\mathrm{NS}}$ & $16.19 \pm 7.9$ & 30-100ng.ml \\
\hline
\end{tabular}

Reference values: ADA, 2015; \#Thoresen, 1995; Enzymatic kit \#\#Nephelometry; ${ }^{*}$ Chemi luminescent immunoassay; NS: Non-Significant

${ }^{*} \mathrm{p}<0.05$.

As revealed in Table 5, 68.1\% of the total type 2 DM subjects had uncontrolled fasting blood sugar levels of which $72.4 \%$ were females. As far as HbA1c and fructos amine is concerned, $57.4 \%$ and $44.7 \%$ of the total subjects respectively had above the normal cut off values. It was found that $36.2 \%$ of the subjects had high urinary microalbumin.

As shown in Table 5, almost half of the type 2 DM subjects (42.6\%) had high hs-CRP levels whereas, only $29.9 \%$ of the total subjects were found to have high homocysteine levels and majority of these subjects were males (50\%).
Association of anthropometric and biophysical profile with the biochemical parameters of type 2 DM subjects is depicted in Table 5. 19. BMI, WC and WSR was significantly correlated with systolic and diastolic blood pressure. Also, a significant positive correlation was observed for BMI, SBP and DBP with Fasting blood sugar. Whereas, Average blood sugar and HbA1c was found to be positively correlated with WHR and WSR. Hs-CRP was positively correlated with BMI whereas homocysteine was positively correlated with WHR (Table 6). 
Table 5: Number of subjects having normal levels of glycemic and inflammatory parameters vs. high levels.

\begin{tabular}{|c|c|c|c|c|c|c|}
\hline \multirow[t]{2}{*}{ Parameter } & \multicolumn{2}{|c|}{ Male $\mathrm{N}=18$} & \multicolumn{2}{|c|}{ Female $N=29$} & \multicolumn{2}{|c|}{ Total $\mathrm{N}=47$} \\
\hline & $\mathbf{N}$ & $\%$ & $\mathbf{N}$ & $\%$ & $\mathbf{N}$ & $\%$ \\
\hline FBS $<126 \mathrm{mg} / \mathrm{dL}$ & 7 & 38.8 & 8 & 27.6 & 15 & 31.9 \\
\hline $\mathrm{FBS} \geq 126 \mathrm{mg} / \mathrm{dL}$ & 11 & 61.2 & 21 & 72.4 & 32 & 68.1 \\
\hline $\mathrm{HbA} 1 \mathrm{c}<7.5$ & 8 & 44.4 & 12 & 41.4 & 20 & 42.6 \\
\hline $\mathrm{HbA} 1 \mathrm{c} \geq 7.5$ & 10 & 55.5 & 17 & 58.6 & 27 & 57.4 \\
\hline $\mathrm{ABG}<140$ & 4 & 22.2 & 2 & 6.9 & 6 & 12.8 \\
\hline $\mathrm{ABG} \geq 140$ & 14 & 77.8 & 27 & 93.1 & 41 & 87.2 \\
\hline Urinary microalbumin $<25 \mu \mathrm{g} / \mathrm{ml}$ & 9 & 50 & 21 & 72.5 & 30 & 63.8 \\
\hline Urinary microalbumin $>25 \mu \mathrm{g} / \mathrm{ml}$ & 9 & 50 & 8 & 27.5 & 17 & 36.2 \\
\hline Fructosamine $\mathrm{e}^{\sharp} \leq 286 \mu \mathrm{mol} / \mathrm{L}$ & 8 & 44.4 & 18 & 62.1 & 26 & 55.3 \\
\hline Fructosamine $>286 \mu \mathrm{mol} / \mathrm{L}$ & 10 & 55.5 & 11 & 37.9 & 21 & 44.7 \\
\hline hs-CRP \#\# $<3 \mathrm{mg} / \mathrm{L}$ & 10 & 55.5 & 17 & 58.6 & 27 & 57.4 \\
\hline hs-CRP $>3 \mathrm{mg} / \mathrm{L}$ & 8 & 44.4 & 12 & 41.4 & 20 & 42.6 \\
\hline Homocysteine ${ }^{*}<30 \mu \mathrm{mol} / \mathrm{L}$ & 9 & 50 & 24 & 82.7 & 33 & 70.2 \\
\hline Homocysteine $>30 \mu \mathrm{mol} / \mathrm{L}+\mathrm{A} 25: \mathrm{A} 26$ & 9 & 50 & 5 & 17.3 & 14 & 29.9 \\
\hline
\end{tabular}

FBS: Fasting Blood Sugar; ABS: Average Blood Sugar; A1c: Glycated Haemoglobin

Reference value: ADA, 2015; \# thoresen, 1995; Enzymatic kit \#\#Nephelometry; *Chemi luminescent immunoassay.

Table 6: Association of anthropometric and biophysical profile with biochemical parameters of type 2 DM subjects.

\begin{tabular}{|c|c|c|c|c|c|c|c|c|c|c|c|}
\hline & SBP & DBP & FBS & ABS & HbA1c & FSA & Hs- & HC & Ecoli & LAB & BIF \\
\hline WT & NS & NS & $0.32^{*}$ & NS & NS & NS & NS & NS & NS & NS & NS \\
\hline BMI & $0.43^{* *}$ & $0.35^{*}$ & $0.31^{*}$ & NS & NS & NS & $0.30^{*}$ & NS & NS & NS & NS \\
\hline WC & $0.3^{*}$ & $0.29^{*}$ & NS & $0.37^{* *}$ & $0.37^{* *}$ & NS & NS & NS & NS & NS & NS \\
\hline WHR & NS & NS & NS & $0.30^{*}$ & $0.30^{*}$ & $0.37^{* *}$ & NS & $0.29^{*}$ & NS & NS & NS \\
\hline WSR & $0.38^{* *}$ & $0.29^{*}$ & NS & $0.30^{*}$ & $0.30^{*}$ & NS & NS & NS & NS & NS & NS \\
\hline SBP & NS & $0.74^{* *}$ & $0.31^{*}$ & NS & NS & NS & NS & NS & NS & NS & NS \\
\hline DBP & $0.74^{* *}$ & NS & $0.30^{*}$ & NS & NS & NS & NS & NS & NS & NS & NS \\
\hline
\end{tabular}

${ }^{*}$ Correlation values are significant. WT: Weight; WC: Waist Circumference; WHR: Waist Hip Ratio; WSR: Waist Stature Ratio; SBP: Systolic Blood Pressure; DBP: Diastolic Blood Pressure; FBS: Fasting Blood Sugar; ABS: Average Blood Sugar; A1c: Glycated Haemoglobin; FSA; Fructosamine; HC: Homocysteine; LAB: Lactobacillus; BIF: Bifidobacterium 
The inflammatory marker hs-CRP was found to be positively correlated with HbA1c and Average blood sugar whereas homocysteine was found to be positively correlated with FBS and fructos amine. Correlation was observed between the gut microbiota and glycemic status of type 2 DM subjects. Bifido bacteria was found to be negatively correlated with FBS, Average blood sugar and $\mathrm{HbA1c}$. E.coli was positively correlated with average blood sugar, HbA1c, fructos amine and homocysteine (Table 7).

Table 7: Correlation amongst biochemical parameters of type 2 DM subjects.

\begin{tabular}{|c|c|c|c|c|c|c|c|c|c|c|}
\hline & Vit D & FBS & ABS & A1c & FSA & Hs-CRP & HC & Ecoli & LAB & BIF \\
\hline Vit D & NS & $-3.5^{*}$ & NS & NS & NS & NS & $-3.7^{* *}$ & NS & NS & NS \\
\hline FBS & $-3.5^{*}$ & NS & $0.8^{* *}$ & $0.81^{* *}$ & $0.6^{* *}$ & $0.44^{* *}$ & $0.3^{*}$ & NS & NS & $-0.3^{*}$ \\
\hline ABS & NS & $0.81^{* *}$ & NS & NS & $0.73^{* *}$ & $0.42^{* *}$ & NS & $0.37^{* *}$ & NS & $-0.33^{*}$ \\
\hline A1c & NS & $0.81^{* *}$ & $0.9^{* *}$ & NS & $0.76^{* *}$ & $0.40^{* *}$ & NS & $0.39^{* *}$ & NS & $-0.35^{*}$ \\
\hline FSA & NS & $0.6^{* *}$ & $0.6^{* *}$ & $0.7^{* *}$ & NS & NS & $0.45^{* *}$ & $0.33^{*}$ & NS & NS \\
\hline HS-CRP & NS & $0.44^{* *}$ & $0.42^{* *}$ & $0.4^{* *}$ & NS & NS & NS & NS & NS & NS \\
\hline H.C & $-3.7^{* *}$ & $0.3^{*}$ & NS & NS & $0.45^{* *}$ & NS & NS & $0.38^{*}$ & NS & NS \\
\hline Ecoli & NS & NS & $0.37^{* *}$ & $0.39^{* *}$ & $0.33^{*}$ & NS & $0.38^{*}$ & NS & $-0.55^{* *}$ & $-0.57^{* *}$ \\
\hline LAB & NS & NS & NS & NS & NS & NS & NS & $-0.55^{* *}$ & NS & NS \\
\hline BIF & NS & $-0.3^{*}$ & $-0.33^{*}$ & $-0.35^{*}$ & NS & NS & NS & $-0.57^{* *}$ & NS & NS \\
\hline
\end{tabular}

Table 8 reflects the result of stepwise linear regression model summary for strongest predictor of type 2 DM of urban Vadodara. The criterion for probability of factor to enter was 0.05 and to remove was 0.100 . hs-CRP was the strongest predictor of type 2 DM to the accuracy of $22 \%$ in diabetic subjects. Hs-CRP along with low vitamin D levels could predict type 2 DM with accuracy of $42 \%$. Further, adding up high hs-CRP levels, low vitamin D levels and high diastolic blood pressure could predict type 2 DM with the accuracy of $51 \%$. When all the three factors are present in a person, type 2 DM could be predicted with accuracy of $51 \%$.

Table 8: Stepwise regression model summary for strongest predictor of type 2 diabetes mellitus. Dependent Variable: FBS PRE

\begin{tabular}{|c|c|c|c|c|c|c|c|}
\hline \multicolumn{8}{|c|}{ Model Summary } \\
\hline \multirow{3}{*}{ Model } & \multirow{3}{*}{$\mathrm{R}$} & \multirow{3}{*}{ R Square } & \multirow{3}{*}{ Adjusted RSquare } & \multirow{3}{*}{ Std. Error of the Estimate } & \multicolumn{3}{|c|}{ Change Statistics } \\
\hline & & & & & & & \\
\hline & & & & & R Square Change & F Change & df1 \\
\hline 1 & $.47 a$ & 0.229 & 0.212 & 41.406 & 0.229 & 13.364 & 1 \\
\hline 2 & $.65 b$ & 0.429 & 0.403 & 36.023 & 0.2 & 15.456 & 1 \\
\hline 3 & $.717 \mathrm{c}$ & 0.514 & 0.48 & 33.636 & 0.084 & 7.465 & 1 \\
\hline
\end{tabular}

\section{a. Predictors: (Constant), HS-CRP PRE}

\section{b. Predictors: (Constant), HS-CRP PRE, VIT D (PRE)}

\section{c. Predictors: (Constant), HS-CRP PRE, VIT D (PRE), DIAS (pre)}

\section{Discussion}

In the present study both male and female subjects were predominantly obese (72\%). Diabetes has been associated with obesity way back. As per ICMR-INDIAB study, there are 199 million and 16.3 million people with obesity and diabetes respectively in India [14]. Evidence from several studies also indicates that overweight and obesity are associated with an increased risk of diabetes [15]. In obese individuals, adipose tissue liberates increased amounts of non-esterified fatty acids, glycerols, hormones, pro-inflammatory cytokines, and other factors that is associated with development of insulin resistance. When insulin resistance occurs, beta cells of pancreas dysfunction which causes increased blood glucose level leading to type 2 diabetes mellitus [16]. This clearly justifies the association between diabetes and obesity.

Studies have shown that obesity parameters like BMI and waist circumference are significantly higher among type 2 DM subjects [17]. In the present study, most of the subjects (70\%) had abdominal obesity indicating a high risk for the development of NCD's. Asian Indians have increased visceral fat and central 
obesity, and this is referred to as the Asian Indian phenotype $[18,19]$. It has been reported in several studies that visceral fat is associated with abdominal obesity and type 2 diabetes mellitus. Abdominal obesity leads to unfavourable aberrations in the body metabolism of diabetics by desensitizing the insulin receptors which results in decrease of insulin levels [20]. Hence, visceral fat is considered to be one of the links between intra-abdominal obesity and type 2 diabetes mellitus [21,22]. Many epidemiological studies have shown abdominal obesity is an independent risk factor for many cardiac complications too such as coronary heart disease, hypertension, heart failure through its impact on the cardiovascular system $[23,24]$.

In our study, waist circumference was significantly correlated with blood pressure and HbA1c. A cohort study on diabetes reported that waist circumference was positively associated with the incidence of type 2 diabetes [25]. In a crosssectional survey, waist circumference was found to be positively correlated with blood pressure and fasting blood glucose [26]. Present study elicited that there is positive correlation between BMI and hs-CRP levels. Similar studies have shown that obesity is linked to hs-CRP levels and is therefore known as low grade inflammatory disease $[27,28]$. Another metabolic disease study indicated that hs-CRP level is associated with central obesity [29].

Studies have shown an association between hypertension and type 2 diabetes, and their concordance is continuously high in populations. Present study elicited that about $40 \%$ of the Type $2 \mathrm{DM}$ subjects suffered from hypertension. Significant positive correlation was observed between hypertension and fasting blood sugar. Hypertension and type 2 diabetes were found to increase stroke risk independently, and their combination increased the risk drastically [30]. A significant correlation between BMI and blood pressure was also found in the present study. Presence of hypertension among obese subjects was found to be $50 \%$. A study by Colosia [31] showed that $70 \%$ of the obese type 2 DM Asian suffer from hypertension. Obesity has also been commonly associated with the over activity of the SNS where long-term sympathetic activation could rise arterial pressure by causing peripheral vasoconstriction and by increasing sodium reabsorption from the renal tubular [32]. The coexistence of hypertension and type 2 diabetes is a major contributor for the development of macrovascular and microvascular complications in type $2 \mathrm{DM}$ people. When hypertension exist together with diabetes, the risk of CVD is increased by $75 \%$ which further contributes to the overall morbidity and mortality [33].

In the present study, the glycemic status of the type $2 \mathrm{DM}$ subjects showed that the mean FBS, ABG, HbA1c, fructos amine and urinary glucose values of the total subjects were higher than the normal cut off. The mean HbA1c values were found to be $8.2 \%$ in type 2 DM subjects. Similarly, a 26week double blind placebo control study showed that the mean baseline value of HbA1c was 9.3\% [34]. American College of Physicians in 2018 announced that patients with type $2 \mathrm{DM}$ should be treated to achieve an HbA1c between 7-8\% rather than 6.5-7\%. However, current ACP guidelines are not applicable to Indian population as they differ in genotype, phenotype and lifestyle factors from US. So, as per ICMR and API recommendation (6.5-7\%), 57.4\% of the subjects had higher HbA1c levels [35].

The relation between low-grade inflammation and insulin resistance (IR) has long been known. Present study showed higher hs-CRP levels in type 2DM subjects. Evidence shows that inflammation may play a crucial intermediary role in the pathogenesis of type 2 diabetes, thus relating diabetes to a number of commonly coexisting conditions thought to originate via inflammatory mechanisms. Fasting blood sugar was independently associated with hs-CRP levels ( $\mathrm{r}=0.44)$. A large population-based study in Iran evaluated that hs-CRP is significantly correlated with FBS and WC [36]. On the other hand, some studies reported that elevation of CRP is an indicator of development of T2DM [37]. There was a linear increasing trend in the incidence of type $2 \mathrm{DM}$ as the baseline CRP quartile increased [38,39]. All these findings support the chronic low-grade inflammation in the development of type $2 \mathrm{DM}$.

Of late, Hyper homo cysteinemia has emerged as a risk factor for cardiovascular diseases. Homocysteine is a sulfur-containing amino acid formed during the metabolism of methionine. Elevated levels of homocysteine are toxic to vascular endothelium [40], inducing endothelial dysfunction and contributing to development of atherosclerosis independent of standard CVD risk factors in diabetic subjects [41]. High plasma levels of insulin seem to influence homocysteine metabolism, possibly through effects on glomerular filtration or by influencing activity of key enzymes in homocysteine metabolism, including 5,10-methylenetetrahydrofolate reductase (MTHFR) or cystathione $\beta$-synthase (CBS) [42]. This study found strong correlation between glycemic parameters and homocysteine. Similar study reported that hyper homo cysteinemia is associated with hyperinsulinemia and a relationship between elevated homocysteine levels and diabetes mellitus has emerged [8]. However, a study has also shown that fasting homocysteine levels are similar in subjects with type 2 diabetes and nondiabetic control subjects [43].

Newer researches have also reported the association between type and number of gut microflora and diabetes. The two most beneficial micro-organisms found abundantly in the gut are Lactobacillus and Bifidobacterium with typical bacterial counts of 108-109 and 109-1011 per gram of stool respectively in a healthy human gut [44]. In the present study the mean bacterial counts for Lactobacillus and Bifidobacterium were much lower than the healthy individuals. Studies have shown that there is lower establishment of beneficial bacteria and higher establishment of harmful bacteria in diabetic and hyper lipidemic subjects $[45,46]$. In the present study, a strong positive correlation was observed between E.Coli and glycemic parameters as well as homocysteine levels.

As shown earlier, obesity was strongly correlated with inflammatory marker. It has been shown that gut microflora is linked with chronic diseases such as obesity. Animal models have revealed that microbiota of obese people have higher capacity 
to harvest energy from food that in turn provide substrates that activate the lipogenic pathway. LPS is the major component of the outer membrane of Gram-negative bacteria and is an endotoxin that causes inflammation after entering the circulation. This suggest that change in gut microflora compositions will led to increase in LPS levels $[47,48]$. LPS are absorbed by enterocytes and they are circulated into plasma and couples to chylomicrons [49]. This lead to macrophage influx into visceral adipose tissue, activation of hepatic cells and insulin resistance. It has been recently shown that the LPS induced signalling cascade via toll like receptor 4 (TLR4) impairs pancreatic beta cell function via suppressed glucose induced insulin secretion and decrease mRNA expression of pancreas [50].

\section{Conclusion}

The strongest predictors of type 2 diabetes mellitus in the present cross-sectional study emerged as raised hs-CRP followed by low Vitamin D levels and high diastolic blood pressure.

\section{References}

1. Huizinga MM, Rothman RL (2006) Addressing the diabetes pandemic: A comprehensive approach. Indian J Med Res 124(5): 481-484.

2. Bhambhani GD, Bhambhani RG, Thakor NC (2005) Lipid profile of patients with diabetes mellitus: a cross sectional study. Int J Res Med Sci 3(11): 3292-3295.

3. Fryirs MA, Barter PJ, Appavoo M, Tuch BE, Tabet F, et al. (2010) Effects of high-density lipoproteins on pancreatic $\beta$-cell insulin secretion. Arterioscler Thromb Vasc Biol 30(8): 1642-1648.

4. Asmat U, Abad K, Ismail K (2016) Diabetes mellitus and oxidative stress-a concise review. Saudi Pharm J 24(5): 547-553.

5. Amartey NA, Nsiah K, Mensah FO (2015) Plasma levels of uric acid, urea and creatinine in diabetics who visit the clinical analysis laboratory (can-lab) at Kwame Nkrumah university of science and technology, Kumasi, Ghana. J Clin Diagn Res 9(2): BC05-BC09.

6. Adler AI, Stevens RJ, Manley SE, Bilous RW, Cull CA, et al. (2003) Development and progression of nephropathy in type 2 diabetes: the United Kingdom prospective diabetes study (UKPDS64). Kidney Int 63(1): 225-232.

7. Rodríguez M, Guerrero R (1999) Increased levels of C-reactive protein in noncontrolled type II diabetic subjects. Journal of Diabetes and Its Complications 13(4): 211-215

8. Meigs JB, Jacques PF, Selhub J, Singer DE, Nathan DM, et al. (2001) Fasting plasma homocysteine levels in the insulin resistance syndrome: the framingham offspring study. Diabetes care 24(8): 1403-1410.

9. Mahendra A, Sheth M (2013) Fructooligosaccharide (FOS) Supplementation in Type 2 Diabetic Adults Improves Systolic Blood Pressure, Serum Lipid, and Gut Microbiota.

10. WuX, MaC, Han L, Nawaz M, Gao F, etal. (2010) Molecular characterisation of the faecal microbiota in patients with type II diabetes. Curr Microbiol 61(1): 69-67

11. Sharma R (2012) Kuppuswamy's Socioeconomic Status Scale revision for 2011 and formula for real-time updating. Indian J Pediatr 79(7): 961962.

12. Mueller WH, Martorell R, Lohman TG, Roche AF (1988) Anthropometric standardization reference manual. Anthropometric standardization reference manual.

13. FAO/WHO 2001. Expert Consultation. Report of a joint FAO/WHO
Expert Consultation. Health and nutritional properties of probiotics in food including powder milk and live lactic acid bacteria.

14. Mohan V, Anjana RM, Pradeepa R, Deepa M, Datta M, et al. (2011) Prevalence of diabetes and prediabetes (impaired fasting glucose and/ or impaired glucose tolerance) in urban and rural India: phase I results of the Indian council of medical research-India DIABetes (ICMR-INDIAB) study. Diabetologia 54(12): 3022-3027.

15. Mokdad AH, Earl SF, Barbara A, William HD (2003) Prevalence of obesity diabetes and obesity-related health risk factors. JAMA 289(1): 76-79.

16. Kahn SE, Hull RL, Utzschneider KM (2006) Mechanisms linking obesity to insulin resistance and type 2 diabetes. Nature 444(7121): 840-846.

17. Mohan V, Gokulakrishnan K, Deepa R, Shanthirani CS, Datta M (2005) Association of physical inactivity with components of metabolic syndrome and coronary artery disease the Chennai urban population study (CUPS No 15). Diabet Med 22(9): 1206-1211.

18. Joshi SR (2003) Metabolic syndrome-emerging clusters of the Indian phenotype. J Assoc Physicians India 51: 445- 446.

19. Shetty P (2012) India's diabetes time bomb. Nature 485(7398): S14-S16

20. Parikh P, Mani UV, Iyer UM (2002) Abdominal adiposity and metabolic control in patients with type 2 diabetes mellitus. Nutr Diabetes 22(1): $28-34$

21. Chen MP, Chung FM, Chang DM, Tsai JC, Huang HF, et al. (2005) Elevated plasma level of visfatin/pre-B cell colony-enhancing factor in patients with type 2 diabetes mellitus. J Clin Endocrinol Metab 91(1): 295-299.

22. Ambady R, Chamukuttan S, Kapur A, Vijay V, Mohan V, et al. (2001) High prevalence of diabetes and impaired glucose tolerance in India: national urban diabetes survey. Diabetologia 44(9): 1094-1101.

23. Lapidus L, Bengtsson C, Larsson B, Penned K, Rybo E, et al. (1984) Distribution of adipose tissue and risk of cardiovascular disease and death: a 12 year follows up of participants in the population study of women in Gothenburg, Sweden. Br Med J 289(6454): 1257-1261.

24. Esser N, Legrand P, Piette S, Scheen J, Paquot AJ (2014) Inflammation as a link between obesity, metabolic syndrome and type 2 diabetes. Diabetes Res Clin Pract 105(2): 141-150.

25. Snijder MB, Dekker JM, Visser M, Bouter LM, Stehouwer CA, et al. (2003) Associations of hip and thigh circumferences independent of waist circumference with the incidence of type 2 diabetes: the hoorn study. Am J Clin Nutr 77(5): 1192-1197.

26. Manios Y, Karatzi K, Protogerou AD, Moschonis G, Tsirimiagou C, et al. (2018) Prevalence of childhood hypertension and hypertension phenotypes by weight status and waist circumference: the healthy growth study. Eur J Nutr 57(3): 1147-1155.

27. Rawson ES, Freedson PS, Osganian SK, Matthews CE, Reed G, et al. (2003) Body mass index, but not physical activity, is associated with C-reactive protein. Med Sci Sports Exerc 35(7): 1160-1166.

28. Bekkelund, SI, Jorde R (2017) Lean body mass and creatine kinase is associated with reduced inflammation in obesity. Eur J Clin Invest 47(11): 803-811.

29. Ebrahimi M, Heidari AR, Shoeibi S, Mirhafez SR, Moohebati M, et al. (2016) Association of serum HS-CRP levels with the presence of obesity, diabetes mellitus, and other cardiovascular risk factors. J Clin Lab Anal 30(5): 672-676.

30. Hu G, Sarti C, Jousilahti P, Peltonen M, Qiao Q, et al. (2005) The impact of history of hypertension and type 2 diabetes at baseline on the incidence of stroke and stroke mortality. Stroke 36(12): 2538-2543.

31. Colosia AD, Palencia R, Khan S (2013) Prevalence of hypertension and obesity in patients with type 2 diabetes mellitus in observational studies: a systematic literature review. Diabetes Metab Syndr Obes 6 : 327-328. 
32. Rahmouni K, Correia MG, Haynes WG, Mark AL (2005) Obesity associated hypertension: new insights into mechanisms. Hypertens 45(1): 9-14.

33. Berraho M, Achhab El, Benslimane Y, Rhazi A, Chikri KE, et al. (2012) Hypertension and type 2 diabetes: a cross-sectional study in Morocco (EPIDIAM Study). Pan Afr Med J 11: 52.

34. Rosenstock J, Rendell MS, Gross JL, Fleck PR, Wilson CA, et al. (2009) Alogliptin added to insulin therapy in patients with type 2 diabetes reduces $\mathrm{HbA1} \mathrm{c}$ without causing weight gain or increased hypoglycaemia. Diabetes Obes Metab 11(12): 1145-1152.

35. API-ICP Guidelines on Diabetes 2007.

36. Ebrahimi M, Heidari AR, Shoeibi S, Mirhafez SR, Moohebati M, et al. (2016) Association of serum hs-CRP levels with the presence of obesity, diabetes mellitus, and other cardiovascular risk factors. J Clin Lab Anal 30(5): 672-676.

37. Wang X, Bao W, Liu J, OuYang YY, Wang D, et al. (2013) Inflammatory markers and risk of type 2 diabetes: a systematic review and metaanalysis. Diabetes care 36(1): 166-175.

38. Festa A, Agostino D, Tracy R, Haffner RP SM (2002) Elevated levels of acute-phase proteins and plasminogen activator inhibitor-1 predict the development of type 2 diabetes: the insulin resistance atherosclerosis study. Diabetes 51(4): 1131-1137.

39. Rubio E, Soriguer F, Gutiérrez C, Garrido L, Adana MSR, et al. (2013) Creactive protein and incidence of type 2 diabetes in the Pizarra study. Eur J Clin Invest 43(2): 159-167.

40. Welch GN, Loscalzo J (1998) Homocysteine and atherothrombosis. $\mathrm{N}$ Engl J Med 338(15): 1042-1050.

41. Hoogeveen EK, Kostense PJ, Jakobs C, Dekker JM, Nijpels G, et al. (2000) Hyper homocysteinemia increases risk of death, especially in type 2 diabetes: 5-year follow-up of the Hoorn Study. Circulation 101(13): 1506-1511.
42. Gallistl S, Sudi K, Mangge H, Erwa W, Borkenstein M (2000) Insulin is an independent correlate of plasma homocysteine levels in obese children and adolescents. Diabetes Care 23(9): 1348-1352.

43. Munshi MN, Stone A, Fink L, Fonseca V (1996) Hyper homocysteinemia following a methionine load in patients with non-insulin-dependent diabetes mellitus and macrovascular disease. Metabolism 45(1): 133135 .

44. Andrew LW, Delphind MA, Saulnier, Gibson GR (2008) Gastrointestinal microflora and interactions with gut mucosa. Chapter 2. Handbook of prebiotics by Gibson GR and Roberfroid MB. CRC press, Taylor and Francis group USA, pp. 11-38.

45. Vaidya R, Sheth M (2011) Resistant starch analysis in raw and processed Indian foods and understanding the mechanism of its action through gut microbiota in Indian diabetics PhD thesis. Dept, of Foods and Nutrition. The M.S. University of Baroda, India.

46. Pamami S, Sheth M (2011) Indian fermented milk (Delhi) fortified with probiotic bacteria and inulin improves serum lipid, blood glucose levels and gut microflora. Journal of The Indian Academy of Geriatrics 7: 1-5.

47. Zhao L (2013) The gut microbiota and obesity: From correlation to causality. Nat Rev Microbiol 11(9): 639-647.

48. Cani PD, Bibiloni R, Knauf C, Waget A, Neyrinck AM, et al. (2008) Changes in gut microbiota control metabolic endotoxemia induced inflammation in high-fat diet-induced obesity and diabetes in mice. Diabetes 57(6): 1470-1481.

49. Clemente M, Queipo MI, Murri M, Boto M, Perez P, et al. (2012) Endotoxin increase after fat overload is related to postprandial hypertriglyceridemia in morbidly obese patients. J Lipid Res 53(5): 973-978.

50. Laetitia R, Paul A, Marinescu D, Shao W, Prakash S (2013) Effect of probiotics Lactobacillus and Bifidobacterium on gut-derived lipopolysaccharides and inflammatory cytokines: an in vitro study using a human colonic microbiota model. J Microbiol Biotechnol 23(4): 518526.
Creative Commons Attribution 4.0 International License

For possible submissions Click Here

\section{Submit Article}

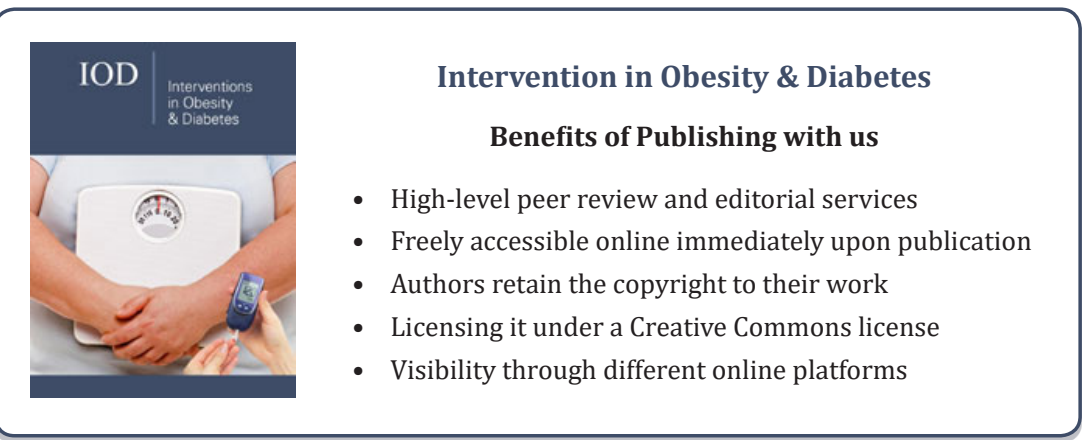

